\title{
CAUSES OF DELAYS IN THE CONSTRUCTION PHASE OF CHINESE BUILDING PROJECTS
}

\begin{abstract}
Purpose - Delays during construction are one of the common scenarios in the construction industry. This research aims to identify the primary causes of delays in the construction phase of building construction projects in China.

Design/methodology/approach - Questionnaire survey approach was adopted across the four typical cities in China, namely, Beijing, Shanghai, Chongqing, and Shenzhen. One hundred and fifteen sets of valid responded questionnaires were collected and analysed.

Findings - The results show that the causes of variations, delays in progress payments, exceptionally low bids, and subcontractors' poor performance and communication issues were the most important causes of delays in China.

Originality/value - This research is the first questionnaire survey on the causes of delays in the construction phase of building construction projects in China. The comparative analysis shows two unique causes of delays in the Chinese construction industry, such as "difficulty in claiming indemnity" and "unreasonable upfront capital demanded by client". It also reveals different ranked causes of delays as per distinguished political and economic situations in China. The research findings can be referred by construction projects in other countries that are funded or partnered with China.
\end{abstract}

Keywords: Delays; Time Overrun; Construction Phase; Building Projects; Risk Management; Empirical Analysis; Comparative Analysis; Construction Projects; Empirical Analysis; China. 


\section{INTRODUCTION}

Completion on time is one of fundamental performance indicators in construction projects. In particular, schedules are used by project managers to control and manage construction projects and, thereby, contribute to the projects' performance (Zavadskas et al., 2014). However, the progress of projects is often poorly controlled. Causes of cost overrun have been studied (Flyvbjerg 2004). For example, the lack of control increases project costs (Sinesilassie et al., 2017) and reduces project quality (Agyekum-Mensah et al., 2017). Delays can also have serious legal consequences (Leishman 1991) and project risks (Zhi 1995). Most of existing studies focused on the causes of delays in construction projects during the construction stage, such as Hong Kong (Lo et al. 2006), Malaysia (Sambasivan et al. 2007), Egypt (Abd El-Razek et al. 2008), Jordan (Sweis et al. 2008), Zambia (Kaliba et al. 2009), Iran (Khoshgoftar et al., 2010), Turkey (Kazaz et al. 2012), India (Doloi et al. 2012), Pakistan (Choundhry et al. 2014), Singapore (Hwang et al. 2014), Chile (Ballesteros-Pérez et al. 2015), Cambodia (Santoso and Soeng, 2016), and United Arab Emirates (Mpofu et al., 2017). Some studies also addressed the delays at the pre-construction stage through identifying causes of delays from the planning and design activities (Yang and Wei 2010), making clear contract conditions on delays (Chong et al. 2014), and designing a risk management methodology at the design stage (Albogamy, A. and Dawood 2015).

Surprisingly, although researchers have identified key risks in constructions in China (Zou et al. 2007), none of the previous studies has investigated the causes of delays in building construction projects in China. This oversight is a vital research gap that needs to be addressed because the existing research findings may not be relevant to China due to the political and economic differences. Furthermore, the Chinese construction industry has developed into one of the largest markets in the world, employing approximately 45 million workers, completing 19.36 trillion RMB (about \$2914billion US) of construction in 2016, which contributes significantly to China's 2016 gross domestic product (China 2017). The construction industry is in transition from its historically centrally planned economy to a more market-based industry. Examples of these changes include the development of capital markets and standardization of contracts and processes. However, the data collected as part of the current work and literature indicate that China's construction industry continues to be deeply influenced by the nation's centrally planned economic system (Luo, Gale 2000).. An in-depth understanding on the delays of building construction projects that are specific to China is critical for improving 
Chinese construction practices. Therefore, the research aims to identify the primary causes of delays in the construction phase of building construction projects in China. Quantitative research approach was adopted by using questionnaire survey method across the four typical cities in China, namely, Beijing, Shanghai, Chongqing, and Shenzhen. Two comparative analyses were designed to (a) test any different views among the respondents on the analyzed data, and (b) compare the research findings with the related previous studies.

The remainder of this paper is structured as follows. A review of previous research on the causes of delays in different countries is used to establish the knowledge gap for the current work. The general research approach and survey tool development and use are then described. Results are described with the mean values of participant responses. The expected value approach is adopted to investigate the impact of the causes of delays on project schedule performance Finally, the results are compared with previous research to provide an insightful understanding for Chinese building construction.

\section{RELATED STUDIES ON CAUSES OF DELAY}

Generally, delays may be caused by the client (compensable delays), the contractors (nonexcusable delays), or acts of God or a third party (Majid, McCaffer 1998). Delays can be defined as the time overrun either beyond completion date specified in a contract, or beyond the date that the parties agreed upon for delivery of a project (Assaf and Al-Hejji 2006). Previous research has considered identifying delay causes as a critical step in developing and implementing ways to minimize delays (Ramanathan et al., 2012). Researchers have taken different perspectives for describing delay causes (Hwang et al., 2015). For example, Bramble and Callahan (2010) outlined causes of delays created by clients, designers, contractors, and subcontractors. In contrast, Pickavance (2010) sought to identify management issues that cause delays and reveal poor site management as important causes that impact project productivity. Others have focused on a single project type, such as Assaf et al. (1995), whose work on large building construction projects found 56 delay causes, Mahamid et al.'s (2012) study of road construction projects and Hwang and Leong (2013)'s comparative analysis between traditional and green construction projects.

Geographic locations as defined by nations have been a focus of several investigations of delay causes. Koushki et al. (2005) found change orders, clients' financial constraints, and clients' lack of experience to be 
the most important causes of delays in Kuwait. Aibinu and Odeyinka (2006) identified 44 causes of delays in building projects in Nigeria and suggested that they have similar levels of impact on projects. El-Razek et al. 2008) used a survey to identify 32 causes of delays in Egypt and grouped them according to the responsible agent (contractor, consultant, or client). Abdul-Rahman et al. (2006) found financial problems, worker shortage, and changes in the project requirements to be delay factors in Malaysia. In Hong Kong, Chan and Kumaraswamy's study (1997) identified five delay causes: poor risk management and supervision, unforeseen site conditions, slow decision making, client-initiated variations, and work variations. In addition, similar studies also have been conducted in other countries, including Thailand (Ogunlana et al. 1996), Indonesia (Kaming et al. 1997), Hong Kong (Lo et al. 2006), United Arab Emirates (Faridi, El-Sayegh 2006; Mpofu et al., 2017), Jordan (Sweis et al. 2008), India (Doloi et al. 2012), Turkey (Kazaz et al. 2012), Pakistan (Choudhry et al. 2014), Chile (Ballesteros-Pérez et al. 2015), and Cambodia (Santoso and Soeng, 2016)

Despite this plethora of research on the causes of delays, no consensus has been reached on the factors that affect building construction durations (Sweis et al. 2008). Although some common causes of delay were interconnected (Parchamijalal and Shoar 2017); they are quite generic in nature and lack of detailed discussions by considering from the different culture and practice in their respective countries. Furthermore, very limited data are available for the causes of construction delays in China, especially in the construction phase of building projects.

\section{RESEARCH APPROACH AND SURVEY DEVELOPMENT}

The variables for Chinese building construction projects should consider all types of causes of delays at the beginning stage of this research. Subsequently, certain filtrations of them need to be conducted through interviewing local experts and pilot study to confirm the right and potential causes of delays for the use of questionnaire surveys in this research area. Hence, firstly, the survey of Chinese construction professionals was used to collect data on the causes of delays in the construction phase of building projects. However, a critical issue in survey development needs to be addressed, which was to identify potential delay causes that include in the questionnaire as too many unimportant potential causes would decrease participation rate and attention paid by the respondents. After reviewing the related literature, 69 potential delay causes were 
identified and needed to be filtered through interviews and pilot study. These causes were then grouped into the seven categories, namely, client related, engineering related, contractor related, human behavior related, project related, external related, and resource related. The categories can provide a comprehensive and clear classification that suits building projects.

To ensure that all the potentially important delay causes were included and to test the effectiveness of the survey for data collection, six local experts were interviewed who consisted of two clients, two contractors and two consultants. All of them have had at least twenty years of working experience in the Chinese construction industry. Each interviewee reviewed the causes and suggested new causes. The interviews sought answers to two questions: "Does this cause affect construction phase project delays in the Chinese construction industry?" and "Are there other causes that might cause construction phase project delays?". Based on these interviews, 6 new potential causes were added, which summed up to a total of 75 causes of delay The new causes are "Unreasonable upfront capital demanded by client", "Delegating insufficient authority to engineer by client", "Ineffectiveness of safety and health system", "Poor relationships between various stakeholders (client, engineer, contractor, and subcontractor)", "Difficulty in claiming indemnity", and "Project stakeholders breach the contract".

However, the response rate would be expected to be too low if respondents were needed to answer 75 questions on delay causes, with two scales of selections on their occurrence and impact. Therefore, a pilot study was used to reduce unimportant delays for Chinese building projects. Four industry experts (senior project managers) and two academic experts (renowned professors) were participated in the pilot study, who have had a very high level of knowledge in Chinese construction delays. The pilot study identified potential causes with small relative expected risk (the product of the frequency and impact size). Possible values ranged from zero (does not occur, has no impact, or both) to 25 (occurs very often and has large impact). Causes with expected relative risk ratings less than or equal to five were eliminated from the pool of potential delay causes. As a result, 37 potential delay causes were finalised and used for the questionnaire survey as shown in Table 1. The questionnaire structure was designed into two parts to uphold its clarity and simplicity. The Part A was the questions for the respondents' biographical information; while the 37 delay causes were asked in the Part B with two scales of selection for its frequency and schedule impact.

Table 1: Pilot Study and Interviews outcomes on causes of delay in Chinese building construction projects 


\begin{tabular}{|c|c|c|c|c|}
\hline Category & Delay Causes & Sources & $\begin{array}{l}\text { Relative } \\
\text { importa } \\
\text { nce } \\
\text { index } \\
\text { (Pilot } \\
\text { Study) }\end{array}$ & Outcomes \\
\hline \multirow[t]{14}{*}{$\begin{array}{l}\text { Client } \\
\text { related }(10 \\
\text { causes })\end{array}$} & Client interference & $\begin{array}{c}\text { Koushki et al. (2005); } \\
\text { Aibinu and Odeyinka } \\
\text { (2006) }\end{array}$ & 10.33 & Selected \\
\hline & Client variations/Changes of scope & $\begin{array}{l}\text { Kumaraswamy (1997); } \\
\text { Lo et al. } 2006\end{array}$ & 17.33 & Selected \\
\hline & Defective materials provided by client & $\begin{array}{l}\text { Abdul-Rahman et al. } \\
\text { (2006); Lo et al. (2006) }\end{array}$ & 4.33 & Deleted \\
\hline & $\begin{array}{l}\text { Delay in approving shop drawings and } \\
\text { sample materials }\end{array}$ & $\begin{array}{c}\text { Aibinu and Odeyinka } \\
\text { (2006); Sambasivan et } \\
\text { al. (2007) }\end{array}$ & 14.83 & Selected \\
\hline & Delay in awarding construction contract & $\begin{array}{l}\text { Lo et al. (2006); Abd El- } \\
\text { Razek et al. (2008) }\end{array}$ & 6.83 & Selected \\
\hline & Delay in progress payments by client & $\begin{array}{l}\text { Sambasivan et al. } \\
\text { (2007); Kazaz et al. } \\
\text { (2012) }\end{array}$ & 15.17 & Selected \\
\hline & $\begin{array}{l}\text { Delay to furnish and deliver the site to the } \\
\text { contractor by the client }\end{array}$ & $\begin{array}{l}\text { Lo et al. (2006); Mpofu } \\
\text { et al., (2017) }\end{array}$ & 9.50 & Selected \\
\hline & Imbalance in the risk allocation & $\begin{array}{c}\text { Lo et al. (2006); } \\
\text { Sambasivan et al. (2007) }\end{array}$ & 5.30 & Deleted \\
\hline & $\begin{array}{l}\text { Late in revising and approving design } \\
\text { documents by client }\end{array}$ & $\begin{array}{c}\text { Lo et al. (2006); } \\
\text { Sambasivan et al. (2007) }\end{array}$ & 11.50 & Selected \\
\hline & $\begin{array}{l}\text { Slowness in decision making process by } \\
\text { client }\end{array}$ & $\begin{array}{c}\text { Aibinu and Odeyinka } \\
\text { (2006); Abd El-Razek et } \\
\text { al. (2008) }\end{array}$ & 12.33 & Selected \\
\hline & Unavailability of the site access area & Mpofu et al., (2017) & 3.83 & Deleted \\
\hline & Unrealistic client requirements & $\begin{array}{l}\text { Aibinu and Odeyinka } \\
\text { (2006); Lo et al. (2006) }\end{array}$ & 5.00 & Deleted \\
\hline & $\begin{array}{l}\text { Unrealistic contract duration imposed by } \\
\text { client }\end{array}$ & $\begin{array}{l}\text { Aibinu and Odeyinka } \\
\text { (2006); Lo et al. (2006) }\end{array}$ & 7.83 & Selected \\
\hline & $\begin{array}{l}\text { Unreasonable upfront capital demanded by } \\
\text { client }\end{array}$ & From the interviews & 14.17 & $\begin{array}{l}\text { Added and } \\
\text { Selected }\end{array}$ \\
\hline \multirow{6}{*}{$\begin{array}{l}\text { Engineer } \\
\text { related ( } 3 \\
\text { causes) }\end{array}$} & $\begin{array}{l}\text { Delays in providing design information and } \\
\text { approval of contractor submission }\end{array}$ & Doloi et al. (2012) & 7.67 & Selected \\
\hline & $\begin{array}{l}\text { Delegating insufficient authority to engineer } \\
\text { by client }\end{array}$ & From the interviews & 10.00 & $\begin{array}{l}\text { Added and } \\
\text { Selected }\end{array}$ \\
\hline & Inaccurate bills of quantities & Sambasivan et al. (2007) & 6.00 & Selected \\
\hline & Inadequate experience of consultant & Lo et al. (2006) & 5.50 & Deleted \\
\hline & Inconsistency in contract documents & $\begin{array}{l}\text { Khoshgoftar et al., } \\
\text { (2010) }\end{array}$ & 3.83 & Deleted \\
\hline & Necessary variations / impossibility & $\begin{array}{l}\text { Lo et al. (2006); } \\
\text { Khoshgoftar et al., } \\
\text { (2010) }\end{array}$ & 4.17 & Deleted \\
\hline
\end{tabular}




\begin{tabular}{|c|c|c|c|c|}
\hline & $\begin{array}{l}\text { Poor communication/coordination between } \\
\text { consultant and other parties }\end{array}$ & $\begin{array}{c}\text { Lo et al. (2006); } \\
\text { Sambasivan et al. (2007 }\end{array}$ & 3.50 & Deleted \\
\hline & $\begin{array}{l}\text { Poor site management \& supervision by } \\
\text { consultant }\end{array}$ & Lo et al. (2006) & 4.83 & Deleted \\
\hline & $\begin{array}{l}\text { Slow coordination and seeking of approval } \\
\text { from concerned authorities }\end{array}$ & Doloi et al. (2012) & 4.50 & Deleted \\
\hline \multirow{14}{*}{$\begin{array}{l}\text { Contractor } \\
\text { related }(11 \\
\text { causes) }\end{array}$} & Delay caused by Domestic Subcontractor & $\begin{array}{l}\text { Aibinu and Odeyinka } \\
\text { (2006) }\end{array}$ & 9.83 & Selected \\
\hline & Delay caused by Nominated Subcontractor & Kazaz et al. $(2012$ & 11.67 & Selected \\
\hline & $\begin{array}{l}\text { Difficulties in financing project by } \\
\text { contractor }\end{array}$ & $\begin{array}{l}\text { Aibinu and Odeyinka } \\
\text { (2006); Lo et al. (2006) }\end{array}$ & 13.67 & Selected \\
\hline & Exceptionally low bids & $\begin{array}{l}\text { Aibinu and Odeyinka } \\
\text { (2006); Lo et al. (2006) }\end{array}$ & 8.67 & Selected \\
\hline & Ineffectiveness of safety and health system & From the interviews & 8.67 & $\begin{array}{l}\text { Added and } \\
\text { Selected }\end{array}$ \\
\hline & $\begin{array}{l}\text { Improper construction methods } \\
\text { implemented by contractor }\end{array}$ & $\begin{array}{l}\text { Abd El-Razek et al. } \\
\qquad \text { (2008) }\end{array}$ & 4.00 & Deleted \\
\hline & $\begin{array}{l}\text { Ineffective planning and scheduling of } \\
\text { project by contractor }\end{array}$ & $\begin{array}{c}\text { Koushki et al. } \\
\text { (2005)Sambasivan et al. } \\
\text { (2007) }\end{array}$ & 6.50 & Selected \\
\hline & Inexperienced contractor & $\begin{array}{c}\text { Lo et al. (2006); } \\
\text { Sambasivan et al. (2007) }\end{array}$ & 10.83 & Selected \\
\hline & Occurrence of site accidents & Sambasivan et al. (2007) & 3.33 & Deleted \\
\hline & $\begin{array}{l}\text { Poor communication and coordination by } \\
\text { contractor with other parties }\end{array}$ & $\begin{array}{l}\text { Abd El-Razek et al. } \\
\text { (2008) }\end{array}$ & 4.50 & Deleted \\
\hline & $\begin{array}{l}\text { Poor qualification of the contractor's } \\
\text { technical staff }\end{array}$ & $\begin{array}{l}\text { Abd El-Razek et al. } \\
\text { (2008) }\end{array}$ & 11.67 & Selected \\
\hline & Poor workmanship & Doloi et al. (2012) & 7.83 & Selected \\
\hline & Rework due to errors during construction & Kazaz et al. (2012) & 6.17 & Selected \\
\hline & $\begin{array}{l}\text { Unsuitable leadership style of contractor's c } \\
\text { onstruction manager }\end{array}$ & Lo et al. (2006) & 6.50 & Selected \\
\hline \multirow{6}{*}{$\begin{array}{l}\text { Human } \\
\text { behaviour } \\
\text { related ( } 2 \\
\text { causes) }\end{array}$} & $\begin{array}{l}\text { Adversarial/confrontational/controversial } \\
\text { culture }\end{array}$ & Lo et al. (2006); & 1.00 & Deleted \\
\hline & $\begin{array}{l}\text { Delays in the response of project teams for } \\
\text { potential dispute resolution }\end{array}$ & $\begin{array}{l}\text { Abd El-Razek et al. } \\
\text { (2008) }\end{array}$ & 3.50 & Deleted \\
\hline & Labor disputes and strikes & Sambasivan et al. (2007 & 7.33 & Selected \\
\hline & Lack of communication & $\begin{array}{l}\text { Aibinu and Odeyinka } \\
\text { (2006); Sambasivan et } \\
\text { al. (2007 }\end{array}$ & 2.67 & Deleted \\
\hline & Personal conflicts among labors & Sambasivan et al. (2007 & 2.00 & Deleted \\
\hline & $\begin{array}{l}\text { Personality clash between Contractor Agent } \\
\text { and Resident Engineer }\end{array}$ & Sambasivan et al. (2007) & 4.33 & Deleted \\
\hline
\end{tabular}




\begin{tabular}{|c|c|c|c|c|}
\hline & $\begin{array}{l}\text { Poor relationships between various } \\
\text { stakeholders (client, engineer, contractor } \\
\text { and subcontractor) }\end{array}$ & From the interviews & 10.17 & $\begin{array}{l}\text { Added and } \\
\text { Selected }\end{array}$ \\
\hline \multirow{8}{*}{$\begin{array}{l}\text { Project } \\
\text { related (4 } \\
\text { causes) }\end{array}$} & Buildability & Lo et al. (2006) & 2.33 & Deleted \\
\hline & Design errors made by designers & Doloi et al. (2012) & 6.00 & Selected \\
\hline & Designers' delay in work approval & $\begin{array}{c}\text { Lo et al. (2006); } \\
\text { Sambasivan et al. (2007) }\end{array}$ & 10.17 & Selected \\
\hline & Legal disputes between various parts & Sambasivan et al. (2007) & 4.17 & Deleted \\
\hline & Original contract duration is too short & Sambasivan et al. (2007) & 10.17 & Selected \\
\hline & $\begin{array}{l}\text { Type of construction contract (Turnkey, } \\
\text { construction only,) }\end{array}$ & $\begin{array}{l}\text { Abd El-Razek et al. } \\
\text { (2008) }\end{array}$ & 1.67 & Deleted \\
\hline & Unforeseen ground conditions & Sambasivan et al. (2007) & 8.67 & Selected \\
\hline & Works in conflict with existing utilities & Sambasivan et al. (2007) & 3.33 & Deleted \\
\hline \multirow{13}{*}{$\begin{array}{l}\text { External } \\
\text { factor }(2 \\
\text { causes })\end{array}$} & Accident during construction & Sambasivan et al. (2007) & 2.33 & Deleted \\
\hline & $\begin{array}{l}\text { Changes in government regulations and } \\
\text { laws }\end{array}$ & $\begin{array}{l}\text { Aibinu and Odeyinka } \\
\text { (2006); Sambasivan et } \\
\text { al. (2007) }\end{array}$ & 4.17 & Deleted \\
\hline & Civil unrest & Khoshgoftar et al. (2010) & 1.50 & Deleted \\
\hline & Cost escalation & Lo et al. (2006) & 5.17 & Deleted \\
\hline & $\begin{array}{l}\text { Delay in obtaining permits from } \\
\text { municipality }\end{array}$ & Lo et al. (2006) & 2.83 & Deleted \\
\hline & $\begin{array}{l}\text { Delay in performing final inspection and } \\
\text { certification by a third party }\end{array}$ & $\begin{array}{l}\text { Koushki et al. (2005); Lo } \\
\text { et al. (2006) }\end{array}$ & 4.83 & Deleted \\
\hline & Difficulty in claiming indemnity & From the interviews & 14.33 & $\begin{array}{l}\text { Added and } \\
\text { Selected }\end{array}$ \\
\hline & Environmental restrictions & $\begin{array}{l}\text { Khoshgoftar et al., } \\
\text { (2010) }\end{array}$ & 3.67 & Deleted \\
\hline & Inclement weather & $\begin{array}{l}\text { Lo et al. (2006); Abd El- } \\
\text { Razek et al. (2008) }\end{array}$ & 4.33 & Deleted \\
\hline & $\begin{array}{l}\text { Natural catastrophes (earthquakes, flood, etc } \\
\text {.) }\end{array}$ & Lo et al. (2006) & 4.83 & Deleted \\
\hline & Project stakeholders breach the contract & From the interviews & 12.83 & $\begin{array}{l}\text { Added and } \\
\text { Selected }\end{array}$ \\
\hline & Traffic control and restriction at job site & Lo et al. (2006) & 2.67 & Deleted \\
\hline & $\begin{array}{l}\text { Unavailability of utilities in site (such as, } \\
\text { water, electricity, telephone, etc.) }\end{array}$ & Lo et al. (2006) & 2.17 & Deleted \\
\hline \multirow{3}{*}{$\begin{array}{l}\text { Resource } \\
\text { related }(5 \\
\text { causes) }\end{array}$} & Delay in material delivery & $\begin{array}{l}\text { Aibinu and Odeyinka } \\
\text { (2006); Lo et al. (2006) }\end{array}$ & 5.17 & Deleted \\
\hline & $\begin{array}{l}\text { Inadequate resources due to contractor/lack } \\
\text { of capital }\end{array}$ & Lo et al. (2006) & 9.67 & Selected \\
\hline & Lack of skilled labour/technical person & $\begin{array}{l}\text { Aibinu and Odeyinka } \\
\text { (2006); Lo et al. (2006) }\end{array}$ & 9.00 & Selected \\
\hline
\end{tabular}




\begin{tabular}{|l|l|c|c|c|}
\hline & \begin{tabular}{l} 
Late procurement of materials \\
\cline { 2 - 5 }
\end{tabular} & $\begin{array}{c}\text { Aibinu and Odeyinka } \\
(2006) ;\end{array}$ & 6.33 & Selected \\
\cline { 2 - 5 } & Low level of equipment-operator's skill & Lo et al. (2006) & 5.17 & Deleted \\
\cline { 2 - 5 } & Low productivity and efficiency of & Lo et al. (2006) & 3.50 & Deleted \\
\cline { 2 - 5 } & Shortage of construction materials in market & Sambasivan et al. (2007) & 4.33 & Deleted \\
\cline { 2 - 5 } & Shortage of equipment & Lo et al. (2006) & 3.50 & Deleted \\
\cline { 2 - 5 } & Shortage of labors & Khoshgoftar et al., & 9.00 & Selected \\
\cline { 2 - 5 } & Unqualified workforce & Lo et al. (2006); & 9.33 & Selected \\
\hline
\end{tabular}

Apart from that, a second critical issue in the survey development was choosing what information to be gathered from each of the delay causes. As described, delays can pose a major risk to project success. Therefore, the survey was designed to collect data on two important features of delay causes related to the risks they create: frequency of occurrence and size of impact on project schedule performance. Although lengths of delays are typically described in time units (e.g., days, weeks, months), delays due to the same cause and with similar frequencies and sizes can have different impacts on project performance. To make clear this, respondents were asked to rate delay cause frequency and impact size on two project-size-independent Likert scales. The frequency scale ranged from 1 to 5 , indicating $1=$ rarely, $2=$ seldom, $3=$ sometimes, $4=$ often, and $5=$ very often. Similarly, the impact scale ranged from 1 to 5 , indicating $1=$ negligible, $2=$ small, $3=$ moderate, $4=$ large , and $5=$ very large .

\subsection{Target Respondents}

The targeted respondents were experienced construction professionals in the primary participant organizations in the construction phase of Chinese building projects. The traditional design-bid-build process is the dominant construction procurement process in China. During the construction phase clients, construction consultants, and contractors are the principal parties of the construction process. Therefore, these three firm types were chosen for the current work, and projects were restricted to the construction phase of design-bid-build projects. Respondents from firms with significant experience in building construction were sought. In China each client, 
contractor, and consulting firm is ranked into a class and only firms in certain classes are allowed to work in specific construction market segments, defined by project size and geographic location (see Lu et al. 2008). Firms are classified based on six factors: 1) registered capital, 2) throughput, 3) previous performance, 4) technical staff, 5) technical facilities, and 6) fixed assets. Clients and contractors were ranked into one of four classes. Consulting firms were ranked into one of three classes. The firms used in the survey were limited to those in the highest classes that focus on the construction of buildings, thereby increasing the likely experience level of respondents. Diversity of respondents across geographic locations was also sought to reflect the Chinese construction industry as a whole (versus centers of intense construction or other atypical conditions). Therefore, firms from four typical cities in China (Beijing, Shanghai, Chongqing, and Shenzhen) were used., which most of the projects have been developing in the areas.

To cope with the need for the survey to be representative of the whole construction industry in China, the authors monitored the responses being received weekly and ensured a balance from the responded questionnaires. Consequently, a total of 320 responses ( 80 firms from each city) were distributed. All responses were collected in a spreadsheet for analysis.

\subsection{RESPONSES AND RESULTS}

A total of 115 valid responses $(36 \%)$ were collected. Respondents were relatively evenly distributed across firm type (38\% client, $35 \%$ contractor and $27 \%$ consultant), location (24\% Beijing, $22 \%$ Shanghai, $27 \%$ Shenzhen and 27\% Chongqing), and organization ownership (24\%-39\% of respondents in each ownership type). Most (74\%) were senior engineers or managers and over $99 \%$ had at least ten years of construction experience. Based on the diversity of characteristics and experience of the respondents the results were viewed as representative of the target population. The sample size was considered sufficient based on the Central Limit Theorem, where the mean of the samples would approach to a normal distribution (Araujo and Gine, 1980). Nevertheless, Cronbach's coefficient alpha (Develles 1991) values were calculated (Carmines, Zeller 1979) to check and determine the internal reliability of the frequency and impact size data using:

$$
\alpha=\mathrm{Kc} /(\mathrm{v}+(\mathrm{K}-1) \mathrm{c})
$$


where: $\alpha-$ Cronbach's coefficient alpha

$\mathrm{K}$ - the number of components

$\mathrm{C}$ - the average of covariances between the components

$\mathrm{v}$-variance of each component.

Alpha values measure the intercorrelations of data. Values cannot exceed 1.0 and those greater than 0.7 are considered acceptable (Nunnally, Bernstein 1994). The alpha value for the frequency data was 0.874 and 0.911 for the impact size data. These values confirmed that the data were internally reliable.

Chan and Kumaraswamy's research (1996) was extended to calculate the Mean Respondent Frequency Rating and Mean Respondent Impact Size Rating, as follows:

$$
\begin{aligned}
& \text { Mean Respondent Frequency Rating }=\frac{\sum f \times a}{N} \\
& \text { Mean Respondent Impact Size Rating }=\frac{\sum s \times a}{N}
\end{aligned}
$$

Expected Risk Rating $=(2) \times(3)$

where: a-score given to each cause of delay by the respondents

f-frequency of responses to each score for each cause of delay

s— size of delay of responses to each score for each cause of delay

$\mathrm{N}$ - total number of respondents

The expected risk rating (Heldman 2005; Loosemore et al. 2006) was used to combine the frequency and impact size of the causes of delays into a single measure of risk to project schedule performance. The expected risk created by each cause of delay as perceived by each participant type and all respondents was calculated as the product of its average frequency rating and average impact size rating. By combining the perceived frequency and impact size ratings, the analysis provides a more accurate description of the effects of delay causes than either the frequency or impact size data alone can supply alone. This would clarify and explain better for the primary causes of delays from the project schedule performance. 


\subsection{Frequency Rating}

The mean values of the frequency rating provided by all respondents and by each participant type (client, contractor, or consultant) were calculated for each delay cause. Table 2 shows the survey results for the ten most-frequent causes based on all respondents that listed in descending order of frequency of occurrence. Respondents in aggregate considered delayed progress payments to be the most frequent cause of delays, followed by changes to scope and delays caused by nominated (vs. domestic) subcontractors. Nominated subcontractors are chosen by the owner, in contrast to domestic subcontractors who are chosen by the general contractor and approved by the owner or consultant. This result suggests that the most frequent causes of delay are client related. However, disaggregating the data into respondent types reveals the different perspectives of the project participants. Clients consider the most frequent causes of delays to be those caused by contractors and contractors consider the most frequent causes of delays to be those caused by clients. More specifically, client respondents indicated that delays by subcontractors are the most frequent causes and contractor respondents indicated that payment delays by clients and client changes are the most frequent causes. This reflects the tension between clients and contractors to meet the project objectives of their own organizations that is inherent in the design-bid-build process and provides face validity to the survey results. The responses of consultants are closer to those of contractors than clients, with some exceptions.

Table 2. Rating of Delay Cause Frequencies in Chinese Building Projects

\begin{tabular}{|l|c|c|c|c|c|c|c|c|}
\hline \multirow{2}{*}{ Cause of Delay } & \multicolumn{9}{|c|}{ Project Participant Type } \\
\cline { 2 - 10 } & \multicolumn{2}{|c|}{ Overall } & \multicolumn{2}{c|}{ Client } & \multicolumn{2}{c|}{ Contractor } & \multicolumn{2}{c|}{ Consultants } \\
\cline { 2 - 10 } & $\begin{array}{c}\text { Mean } \\
\text { frequency } \\
\text { rating }\end{array}$ & Rank & $\begin{array}{c}\text { Mean } \\
\text { frequency } \\
\text { rating }\end{array}$ & Rank & $\begin{array}{c}\text { Mean } \\
\text { frequency } \\
\text { rating }\end{array}$ & Rank & $\begin{array}{c}\text { Mean } \\
\text { frequency } \\
\text { rating }\end{array}$ & Rank \\
\hline Delay in progress payments & 3.32 & $\mathbf{1}$ & 2.84 & $\mathbf{5}$ & 3.68 & $\mathbf{1}$ & 3.55 & 1 \\
\hline Variations/Changes of scope & 3.00 & $\mathbf{2}$ & 2.89 & $\mathbf{4}$ & 3.48 & $\mathbf{2}$ & 2.55 & 10 \\
\hline $\begin{array}{l}\text { Delay caused by Nominated } \\
\text { Subcontractor }\end{array}$ & 2.98 & $\mathbf{3}$ & 3.05 & $\mathbf{2}$ & 3.25 & $\mathbf{3}$ & 2.55 & 9 \\
\hline Client interference & 2.96 & $\mathbf{4}$ & 2.98 & $\mathbf{3}$ & 3.08 & $\mathbf{7}$ & 2.77 & 4 \\
\hline $\begin{array}{l}\text { Delay caused by Domestic } \\
\text { Subcontractor }\end{array}$ & 2.91 & $\mathbf{5}$ & 3.14 & $\mathbf{1}$ & 3.00 & $\mathbf{9}$ & 2.48 & 11 \\
\hline $\begin{array}{l}\text { Unreasonable upfront capital } \\
\text { demanded by client }\end{array}$ & 2.88 & $\mathbf{6}$ & 2.14 & 28 & 3.25 & $\mathbf{4}$ & 3.45 & $\mathbf{2}$ \\
\hline Difficulty in claiming indemnity & 2.87 & $\mathbf{7}$ & 2.59 & 13 & 3.15 & $\mathbf{6}$ & 2.90 & $\mathbf{3}$ \\
\hline $\begin{array}{l}\text { Insufficient authority delegated to } \\
\text { engineer by client }\end{array}$ & 2.79 & $\mathbf{8}$ & 2.64 & 11 & 2.98 & $\mathbf{1 0}$ & 2.77 & $\mathbf{5}$ \\
\hline Exceptionally low bids & 2.73 & $\mathbf{9}$ & 2.59 & 14 & 2.93 & 12 & 2.68 & $\mathbf{7}$ \\
\hline Inaccurate bills of quantities & 2.70 & $\mathbf{1 0}$ & 2.68 & $\mathbf{6}$ & 2.95 & 11 & 2.39 & 15 \\
\hline
\end{tabular}




\subsection{Impact Size Rating}

The means of the impact size rating (reflecting relative delay length) provided by all respondents and by each participant type were calculated. Survey results of the ten causes with the greatest impact according to all respondents are shown in Table 3, listed in descending order of size of impact. Exceptionally low bids and labor shortages were considered the causes of the longest delays by all respondents, with less agreement about the size of the delays because of other causes. Clients indicated that the severest causes of delay are contractor related (inadequate resources because of contractor's lack of capital) and project related (unforeseen ground conditions). Contractors indicated that both contractor-related (exceptionally low bids) and client-related (changes to scope) causes had the greatest impacts. Consultants considered the severest causes of delays were tardy progress payments and labor shortages.

Table 3. Impact Size Rating of the Delay Causes

\begin{tabular}{|c|c|c|c|c|c|c|c|c|}
\hline \multirow{3}{*}{ Cause of Delay } & \multicolumn{8}{|c|}{ Project Participant Type } \\
\hline & \multicolumn{2}{|c|}{ Overall } & \multicolumn{2}{|l|}{ Client } & \multicolumn{2}{|c|}{ Contractor } & \multicolumn{2}{|c|}{ Consultants } \\
\hline & $\begin{array}{l}\text { Mean impact } \\
\text { size rating }\end{array}$ & Rank & $\begin{array}{l}\text { Mean impact } \\
\text { size rating }\end{array}$ & Rank & $\begin{array}{l}\text { Mean impact } \\
\text { size rating }\end{array}$ & Rank & $\begin{array}{l}\text { Mean impact } \\
\text { size rating }\end{array}$ & Rank \\
\hline Exceptionally low bids & 3.25 & 1 & 3.05 & 4 & 3.58 & 1 & 3.13 & 7 \\
\hline Labor shortage & 3.17 & 2 & 3.05 & 3 & 3.15 & 9 & 3.39 & 2 \\
\hline Unforeseen ground conditions & 3.14 & 3 & 3.14 & 2 & 3.30 & 5 & 2.94 & 13 \\
\hline Variations/Changes of scope & 3.11 & 4 & 2.96 & 5 & 3.48 & 2 & 2.87 & 15 \\
\hline Contractor lack of capital & 3.11 & 5 & 3.36 & 1 & 2.75 & 21 & 3.23 & 5 \\
\hline Labor disputes and strikes & 3.04 & 6 & 2.77 & 13 & 3.13 & 10 & 3.29 & 4 \\
\hline Short original contract duration & 3.03 & 7 & 2.68 & 16 & 3.38 & 4 & 3.07 & 9 \\
\hline Delay in progress payments & 3.03 & 8 & 2.46 & 24 & 3.30 & 6 & 3.48 & 1 \\
\hline Late procurement of materials & 3.01 & 9 & 2.84 & 9 & 3.10 & 11 & 3.13 & 6 \\
\hline Delay caused by Nominated Subcontractor & 2.95 & 10 & 2.71 & 14 & 3.38 & 3 & 2.74 & 21 \\
\hline
\end{tabular}

\subsection{Expected Risk Rating}

To investigate the impact of the causes of delays on project schedule performance, the survey results were used to model the risk posed by each potential cause of project schedule slippage. The expected risk rating was adopted. The expected risk created by each delay cause as perceived by each participant type and all respondents was calculated as the product of its average frequency rating (from Table 2) and average impact size rating (from Table 3) as shown in Table 4. The three delay causes with the greatest risks were delayed progress payments, variations/changes to scope, and exceptionally low bids. 
The average expected risk rating of the delay causes as perceived by the contractors, consultants, and clients were $7.43,6.82$, and 6.53 , respectively. This indicates that contractors ( 7.43 average risk rating) perceive delay causes as generating the most risk to project schedule performance, followed by consultants (6.82 average risk rating) and clients (6.53 average risk rating). This is consistent with the shifting of schedule risk from clients to builders through most design-bid-build contract documents.

The expected risk model also reveals the previously mentioned differences in participant perspectives. According to clients' view, the largest risk is from domestic (contractor selected) subcontractors. But contractors and consultants consider this as the tenth and twelfth most important risk, respectively. Similarly, both contractors and consultants consider delays in payments by clients to be the largest risk, but clients consider this to be the fourteenth most important risk. Other delay causes have less variance across participants than these two examples, but reveal the different perspectives of the primary participants in the construction phase.

Table 4. Expected Delay Risk Rating by Causes in Chinese Building Projects

\begin{tabular}{|c|c|c|c|c|c|c|c|c|}
\hline \multirow[b]{3}{*}{ Cause of Delay } & \multicolumn{8}{|c|}{ Project Participant Type } \\
\hline & \multicolumn{2}{|c|}{ Overall } & \multicolumn{2}{|c|}{ Client } & \multicolumn{2}{|c|}{ Contractor } & \multicolumn{2}{|c|}{ Consultants } \\
\hline & $\begin{array}{l}\text { Mean } \\
\text { expected } \\
\text { risk } \\
\text { rating }\end{array}$ & Rank & $\begin{array}{c}\text { Mean } \\
\text { expected } \\
\text { risk } \\
\text { rating }\end{array}$ & Rank & $\begin{array}{c}\text { Mean } \\
\text { expected } \\
\text { risk } \\
\text { rating }\end{array}$ & Rank & $\begin{array}{c}\text { Mean } \\
\text { expected } \\
\text { risk } \\
\text { rating }\end{array}$ & Rank \\
\hline Delay in progress payments & 10.06 & 1 & 6.99 & 14 & 12.14 & 1 & 12.35 & 1 \\
\hline Variations/Changes of scope & 9.33 & 2 & 8.55 & 2 & 12.11 & 2 & 7.32 & 9 \\
\hline Exceptionally low bids & 8.87 & 3 & 7.90 & 6 & 10.49 & 4 & 8.39 & 4 \\
\hline Delay caused by Nominated Subcontractor & 8.79 & 4 & 8.27 & 5 & 10.99 & 3 & 6.99 & 13 \\
\hline Delay caused by Domestic Subcontractor & 8.41 & 5 & 8.98 & 1 & 8.85 & 10 & 7.04 & 12 \\
\hline Client interference & 8.29 & 6 & 8.40 & 3 & 8.87 & 9 & 7.42 & 7 \\
\hline Difficulty in claiming indemnity & 8.09 & 7 & 6.42 & 19 & 10.08 & 6 & 8.15 & 5 \\
\hline Short original contract duration & 8.09 & 8 & 7.08 & 12 & 10.24 & 5 & 6.94 & 15 \\
\hline Contractor lack of capital & 7.78 & 9 & 8.33 & 4 & 6.41 & 23 & 8.85 & 3 \\
\hline Amount of upfront capital demanded by client & 7.60 & 10 & 4.58 & 30 & 9.69 & 8 & 10.14 & 2 \\
\hline
\end{tabular}

\subsection{Comparative Analyses}

Two comparative analyses were conducted from the research findings, namely (a) to test any different views among the respondents on the analyzed data, and (b) to compare the research findings with the related previous studies. 
Nonparametric tests were selected to compare the results given by the three groups of respondents. Kruskal Wallis and Mann Whitney U tests were used to analyze the top ten delay causes using the Statistical Package for the Social Sciences (SPSS) software. All causes of three ratings received a value of 0.00 (asymptotic significance) below 0.05 significant p-value, indicating the rejection of the null hypothesis. The null hypothesis means the population means are all equal. This indicates that the there was a statistically significant difference in the delay causes among the respondents. This result is consistent with the fragmented practices in the construction industry in which each party has a different goal in the project especially for the selected traditional design-bid-build process in this research.

Table 5 compares the most important delay causes between the current work and the recent previous studies that were based on their related scope and quantitative research approach. In other words, the comparison excludes the previous works that were under a qualitative research approach. As a result, seven countries were selected and compared, namely, Hong Kong, Egypt, and Malaysia, India, Turkey and United Arab Emirates. All the top-10 delay causes have been listed and sorted in descending order of importance. This ranking can reveal the primary causes of delays in their countries, which the comparative analysis can be conducted quantitively based on its ranking. Nevertheless, the exact comparison of causes is not possible due to different terminologies or phases used in the previous studies. The numbers in parentheses after delay causes indicate the ranking of that delay cause in the current study. If the numbers are smaller than the ranking as in the current study, it means that the causes are more important in the current study and vice versa. Several delay causes are found to be more important in the current study than in other studies, including those related to payments, client changes, coordination, and short initial durations. This suggests that these delay causes are more important in China than other countries. The causes of "difficulty in claiming indemnity" and "unreasonable upfront capital demanded by client" have been found to be an important cause in the current study but not one of the most important causes in the other studies. Particularly, the indemnity here refers to different practices of insurance policies in China (An and Chen 2014). The exceptionally low bids are the common problem and top-ranked cause in the Chinese construction projects but only one of the comparative studies (Hong Kong) has the similar view on this cause. 
Table 5. Comparison of delay causes with the closely related previous studies

\begin{tabular}{|c|c|c|c|c|c|c|c|c|}
\hline Rank & $\begin{array}{c}\text { China } \\
\text { (current study) }\end{array}$ & $\begin{array}{c}\text { Hong Kong } \\
\text { (Lo et al. 2006) }\end{array}$ & $\begin{array}{c}\text { Egypt } \\
\text { (Abd El-Razek et al. } \\
\text { 2008) }\end{array}$ & $\begin{array}{c}\text { Malaysia } \\
\text { (Sambasivan et al. 2007) }\end{array}$ & $\begin{array}{c}\text { Iran } \\
\text { (Khoshgoftar et al., } \\
\text { 2010) }\end{array}$ & $\begin{array}{c}\text { India } \\
\text { (Doloi et al. 2012) }\end{array}$ & $\begin{array}{c}\text { Turkey } \\
\text { (Kazaz et al. 2012) }\end{array}$ & $\begin{array}{c}\text { United Arab } \\
\text { Emirates } \\
\text { (Mpofu et al., 2017) }\end{array}$ \\
\hline 1 & $\begin{array}{l}\text { Delay in progress } \\
\text { payments }\end{array}$ & $\begin{array}{l}\text { Inadequate } \\
\text { resources because } \\
\text { of contractor/lack } \\
\text { of capital (9) }\end{array}$ & $\begin{array}{l}\text { Financing by } \\
\text { contractor during } \\
\text { construction }(9)\end{array}$ & $\begin{array}{l}\text { Contractor's improper } \\
\text { planning }\end{array}$ & $\begin{array}{l}\text { Finance and payments } \\
\text { of completed work (1) }\end{array}$ & $\begin{array}{l}\text { Delay in material } \\
\text { delivery by vendors }\end{array}$ & $\begin{array}{l}\text { Design and material } \\
\text { changes (2) }\end{array}$ & $\begin{array}{l}\text { Unrealistic contract } \\
\text { duration imposed by } \\
\text { client (8) }\end{array}$ \\
\hline 2 & $\begin{array}{l}\text { Variations/Changes of } \\
\text { scope }\end{array}$ & $\begin{array}{l}\text { Unforeseen } \\
\text { ground conditions }\end{array}$ & $\begin{array}{l}\text { Delays in contractor's } \\
\text { payment by owner (1) }\end{array}$ & $\begin{array}{l}\text { Contractor's } \\
\text { poor site management }\end{array}$ & Improper planning & $\begin{array}{l}\text { Nonavailability of } \\
\text { drawing/design on } \\
\text { time }\end{array}$ & Delay of payments (1) & $\begin{array}{l}\text { Incomplete design at } \\
\text { the time of tender }\end{array}$ \\
\hline 3 & $\begin{array}{l}\text { Exceptionally low } \\
\text { bids }\end{array}$ & $\begin{array}{l}\text { Exceptionally } \\
\text { low bids (3) }\end{array}$ & $\begin{array}{l}\text { Design changes by } \\
\text { owner or his agent } \\
\text { during construction } \\
\text { (2) } \\
\end{array}$ & $\begin{array}{l}\text { Inadequate contractor } \\
\text { experience }\end{array}$ & Site management & $\begin{array}{l}\text { Financial constraints } \\
\text { of contractor }\end{array}$ & Cash flow problems & $\begin{array}{l}\text { Too many scope } \\
\text { changes and change } \\
\text { orders (2) }\end{array}$ \\
\hline 4 & $\begin{array}{l}\text { Delay caused by } \\
\text { Nominated } \\
\text { Subcontractor }\end{array}$ & $\begin{array}{l}\text { Inexperienced } \\
\text { contractor }\end{array}$ & $\begin{array}{l}\text { Partial payments } \\
\text { during construction } \\
\text { (1) }\end{array}$ & $\begin{array}{l}\text { Inadequate client's finance } \\
\text { and payments for } \\
\text { completed work (1) }\end{array}$ & $\begin{array}{l}\text { Contract management } \\
\text { (8) }\end{array}$ & $\begin{array}{l}\text { Increase in scope of } \\
\text { work (2) }\end{array}$ & $\begin{array}{l}\text { Contractor's financial } \\
\text { problems (9) }\end{array}$ & $\begin{array}{l}\text { Inadequate planning } \\
\text { and scheduling }\end{array}$ \\
\hline 5 & $\begin{array}{l}\text { Delay caused by } \\
\text { Domestic } \\
\text { Subcontractor }\end{array}$ & $\begin{array}{l}\text { Works in conflict } \\
\text { with } \\
\text { existing utilities }\end{array}$ & $\begin{array}{l}\text { Not using professional } \\
\text { construction/contractu } \\
\text { al management }\end{array}$ & $\begin{array}{l}\text { Problems with } \\
\text { subcontractors }(4,5)\end{array}$ & $\begin{array}{l}\text { Lack of } \\
\text { communication } \\
\text { between the parties }\end{array}$ & $\begin{array}{l}\text { Obtaining permissions } \\
\text { from local authorities }\end{array}$ & $\begin{array}{l}\text { Poor labor } \\
\text { productivity }\end{array}$ & $\begin{array}{l}\text { Poor project planning } \\
\text { and control }\end{array}$ \\
\hline 6 & Client interference & $\begin{array}{l}\text { Poor site } \\
\text { management and } \\
\text { supervision by } \\
\text { consultant }\end{array}$ & $\begin{array}{l}\text { Slow delivery of } \\
\text { materials (9) }\end{array}$ & Shortage in material (9) & Subcontractors $(4,5)$ & $\begin{array}{l}\text { Delay in material to } \\
\text { be supplied by the } \\
\text { owner (6) }\end{array}$ & Estimation problems & $\begin{array}{l}\text { Delay in obtaining } \\
\text { permit/approval from } \\
\text { municipality/different } \\
\text { gov. authorities }\end{array}$ \\
\hline 7 & $\begin{array}{l}\text { Difficulty in claiming } \\
\text { indemnity }\end{array}$ & $\begin{array}{l}\text { Unrealistic } \\
\text { contract } \\
\text { duration imposed } \\
\text { by clients ( } 8)\end{array}$ & $\begin{array}{l}\text { Difficulty of } \\
\text { coordination between } \\
\text { various parties } \\
\text { working on the project } \\
(4,5,6)\end{array}$ & Labor supply (9) & $\begin{array}{l}\text { Equipment } \\
\text { availability and failure } \\
\text { (9) }\end{array}$ & $\begin{array}{l}\text { Slow decision from } \\
\text { owner }\end{array}$ & $\begin{array}{l}\text { Lack of feasibility } \\
\text { studies }\end{array}$ & $\begin{array}{l}\text { Poor labour } \\
\text { productivity problems }\end{array}$ \\
\hline 8 & $\begin{array}{l}\text { Short original contract } \\
\text { duration }\end{array}$ & $\begin{array}{l}\text { Environmental } \\
\text { restrictions }\end{array}$ & $\begin{array}{l}\text { Slowness of the owner } \\
\text { decision making } \\
\text { process }\end{array}$ & $\begin{array}{l}\text { Equipment availability } \\
\text { and failure (9) }\end{array}$ & $\begin{array}{l}\text { Shortage in material } \\
\text { (9) }\end{array}$ & $\begin{array}{l}\text { Poor site management } \\
\text { and supervision }\end{array}$ & Construction defects & $\begin{array}{l}\text { Slowness in decision- } \\
\text { making process by } \\
\text { owner }\end{array}$ \\
\hline 9 & $\begin{array}{l}\text { Inadequate resources } \\
\text { due to contractor/lack } \\
\text { of capital }\end{array}$ & $\begin{array}{l}\text { Slow } \\
\text { coordination and } \\
\text { seeking of } \\
\text { approval from } \\
\text { concerned } \\
\text { authorities }\end{array}$ & $\begin{array}{l}\text { The relationship } \\
\text { between different } \\
\text { subcontractors' } \\
\text { schedules }\end{array}$ & $\begin{array}{l}\text { Lack of communication } \\
\text { between parties }\end{array}$ & $\begin{array}{l}\text { Inadequate contractor } \\
\text { experience }\end{array}$ & $\begin{array}{l}\text { Delay in materials } \\
\text { procurement by } \\
\text { contractor }(9)\end{array}$ & $\begin{array}{l}\text { Unbalanced number } \\
\text { of workers }\end{array}$ & Design changes \\
\hline 10 & $\begin{array}{l}\text { Unreasonable upfront } \\
\text { capital demanded by } \\
\text { client }\end{array}$ & $\begin{array}{l}\text { Client } \\
\text { variation/changes } \\
\text { of scope (2) }\end{array}$ & $\begin{array}{l}\text { Preparation of shop } \\
\text { drawings and material } \\
\text { samples }\end{array}$ & $\begin{array}{l}\text { Mistakes during the } \\
\text { construction stage. }\end{array}$ & Change orders (2) & $\begin{array}{l}\text { Unrealistic time } \\
\text { schedule imposed in } \\
\text { contract }\end{array}$ & $\begin{array}{l}\text { Fluctuation in } \\
\text { materials prices }\end{array}$ & $\begin{array}{l}\text { Inadequate site } \\
\text { management, } \\
\text { monitoring and } \\
\text { control }\end{array}$ \\
\hline
\end{tabular}




\section{DISCUSSIONS}

Clients, contractors and consultants have different rankings of the delay causes. For example, clients perceive that the highest risk is due to the delay caused by domestic (contractor selected) subcontractors; while contractors and consultants consider delays in payments by clients to be the highest risk. Moreover, variations or changes of scope have been ranked the second highest risk by clients and contractors, but consultants consider it as the ninth important risk. Their disagreements explain the common scenario in Chinese building construction projects, which leads to the occurrence of delays during the construction stage. Although this situation is mainly due the fragmented practices and different objectives of project stakeholders in the traditional design-bid-build process, it reveals useful references for allocating fairer risks into the design-bidbuild contracts for all contracting parties.

Besides, although differences in terminology in different studies prevent exact comparisons, the results of the current work show some similarities and differences as per the results of previous studies. It reveals two unique causes of delays in the Chinese construction industry, such as "difficulty in claiming indemnity" and "unreasonable upfront capital demanded by client". It also shows different ranked causes of delays. Five of the major causes of delays in Malaysia (Sambasivan et al. 2007) are quite similar to some of the most important causes of delays in the current work: inadequate client's finance and payments for completed work, problems with subcontractors, shortage in material, labor supply, and equipment availability and failure. Iran has a similar top-one ranked cause of delay as in China, which is related to the financial issues or delay in progress payments on the completed works (Khoshgoftar et al., 2010). The timely payment for contractors' works is a problematic issue in China due to the low entry requirements and competitive markets for the Chinese contractors, and the overemphasis on the construction speed under the pressure of the rapid economic growth. These reasons are also relevant and able to explain the need for the upfront capital requested by employers to protect their interest. Meanwhile, the government is streamlining a public service platform for all construction activities and data in China (Ministry of Housing and Urban-Rural Development, China, 2017). It aims to monitor, record and share the construction activities and data for public scrutiny and use. The blacklisted construction stakeholders and organisations' poor credit records will be announced publicly, which this will help to mitigate and/or address the top-ranked causes of delays in the Chinese construction industry. 
During the current evolution process in China, contracting parties are more likely to use guanxi instead of a contract to solve problems due the lack of contractual awareness (Badi et al., 2017). Guanxi describes the rudimentary dynamic in personalized social networks of influence that relates to the cultivated harmony relationships to each other in Chinese culture (Gold et al., 2012). It emphasizes on implicit mutual obligations, reciprocity, and trust. This relates to the emphasis of relational governance in the construction practice instead of contractual governance. It will help in addressing the top-ranked delay causes more effectively instead of purely control them via strict contract provisions. It is because some of the primary delay causes in building construction projects require more on the coordination and communication among stakeholders. This is supported by the recent findings on the common issues on timely and successful sharing of information during the construction stage in building projects, which this can be effectively solved via establishing a clear point of contact; providing clear and understandable information for stakeholders; and timely sharing of information (Tran et al., 2017). Hence, decision makers need to balance and incorporate more relational governance in addressing the primary delay causes.

Apart from that, numerous international construction projects have been initiated and are working with China under the current Belt and Road Initiative, which the total investment is up to US Dollar \$1 trillion (China's State Information Centre, 2017). Many countries have received the investments or partnered with China for the first time on their projects. This research provides useful insights into the Chinese practice and culture in construction projects. The participating countries in this initiative can refer this research in avoiding and managing those top ranked causes of delays proactively. As a result, it would improve project performance via the successful completion of the projects.

\section{CONCLUSIONS}

The research has identified the primary causes of delays in the construction phase of Chinese building projects by surveying construction practitioners on filtered 37 delay causes. The ratings of the perceptions of the relative frequency of different delay causes and schedule impacts were analysed. The results show the most frequent delay causes are delayed progress payments, changes to scope, and delays caused by client-selected subcontractors. The subcontractors would encounter similar delay causes but their problems are mainly due to 
their own poor performance and communication issues. Similarly, the delay causes with the largest impacts on project schedules are exceptionally low bids, labor shortages, and unforeseen ground conditions. The ratings of delay causes by the three participant types vary significantly and are generally consistent with design-bidbuild projects. By combining the analyses of the frequency data and schedule impacts, delayed progress payments, changes to scope, and exceptionally low bids are the three delay causes that generate the most risk to project schedule performance. Subsequently, the findings were compared to the related previous studies from different countries. The comparative analysis shows two unique causes of delays in the Chinese construction industry, such as "difficulty in claiming indemnity" and "unreasonable upfront capital demanded by client". Construction practitioners or decision makers can make appropriate adjustment on their relational or contractual practices in addressing the distinguished and primary causes of delays, especially for those construction projects in other countries that are funded or partnered with China.

Certain limitations need to be considered in the research. The results and conclusions are limited to the scope of the construction phase in Chinese building construction projects. New delay causes could be identified from different types of construction projects as well as other phases of the project lifecycle. Other groups of respondents could also be considered into the research apart from the selected main stakeholders of construction projects. Nevertheless, this research is valid and of significance for the causes of delays in Chinese building construction projects, especially under the traditional design-bid-build procurement system. It renders insightful references into the current culture and practices in China, which serves as a good foundation for implementing the related management strategies. Future research should focus on how project managers can effectively improve project schedule performance by reducing the occurrence of the causes identified and/or mitigating their impacts through the current trend and use of Building Information Modelling (BIM), especially controlling the primary delay causes in the 4D BIM model by leveraging the digital data. The continued expansion of the knowledge and understanding of the causes of construction delays will lead to solutions that improve project performance. 


\section{References}

Abd El-Razek, M. E., Bassioni, H. A., and Mobarak, A. M. (2008). "Causes of delay in building construction projects in Egypt." Journal of Construction Engineering and Management, 134(11), 831-841.

Abdul-Rahman, H., Berawi, M. A., Berawi, A. R., Mohamed, O., Othman, M., and Yahya, I. A. (2006). "Delay mitigation in the Malaysian construction industry." Journal of Construction Engineering and Management, 132(2), 125-133.

Aibinu, A. A., and Odeyinka, H. A. (2006). "Construction delays and their causative factors in Nigeria." Journal of Construction Engineering and Management, 132(7), 667-677.

Agyekum-Mensah, G., Agyekum-Mensah, G., Knight, A. D., \& Knight, A. D. (2017). The professionals' perspective on the causes of project delay in the construction industry. Engineering, Construction and Architectural Management, 24(5), 828-841.Albogamy, A., and Dawood, N. (2015). "Development of a client-based risk management methodology for the early design stage of construction processes: applied to the KSA." Engineering, Construction and Architectural Management, 22(5), $493-515$.

An, Y., \& Chen, J. (2014). Research on the Effectiveness of Risk Sharing in the Management of Construction Contracts. In ICCREM 2014: Smart Construction and Management in the Context of New Technology (pp. 822-831).

Araujo, A., \& Giné, E. (1980). The central limit theorem for real and Banach valued random variables (Vol. 431, p. 432). New York: Wiley.

Assaf, S. A., and Al-Hejji, S. (2006). "Causes of delay in large construction projects.” International Journal of Project Management, 24(4), 349-357.

Assaf, S. A., Al-Khalil, M., and Al-Hazmi, M. (1995). "Causes of Delay in Large Building Construction Projects.” Journal of Management in Engineering, 11(2), 45-50.

Badi, S., Wang, L., \& Pryke, S. (2017). Relationship marketing in Guanxi networks: A social network analysis study of Chinese construction small and medium-sized enterprises. Industrial Marketing Management, 60, 204-218.

Ballesteros-Pérez, P., del Campo-Hitschfeld, M. L., González-Naranjo, M. A., and González-Cruz, M. C. (2015). "Climate and construction delays: case study in Chile." Engineering, Construction and Architectural Management, 22(6), 596-621.

Bramble, B. B., and Callahan, M. T. (2010). Construction Delay Claims, 4 ed., Aspen Publishers, New York.

Carmines, E. G., and Zeller, R. A. (1979). Reliability and Validity Assessment, Sage Publications, Inc.

Chan, D. W. M., and Kumaraswamy, M. M. (1997). "Comparative study of causes of time overruns in Hong Kong construction projects." International Journal of Project Management, 15(1), 55-63.

Chang, A. S.-T. (2002). "Reasons for cost and schedule increase for engineering design projects." Journal of Management in Engineering, 18(1), 29-36.

China, N. B. o. S. o. P. R. (2015). China Statistical Yearbook 2014, China Statistics Press, Beijing.

China's State Information Centre (2017).Belt and Road Portal. Retrieved from https://eng.yidaiyilu.gov.cn/index.htm.

Chong, H. Y., Tan, C. K., and Munir, O. (2014). Revisiting UK Delay and Disruption Protocol: Distinguished Features for Contract Drafting. Journal of Management in Engineering, 06014004.

Choudhry, R. M., Aslam, M. A., Hinze, J. W., and Arain, F. M. (2014). Cost and Schedule Risk Analysis of Bridge Construction in Pakistan: Establishing Risk Guidelines. Journal of Construction Engineering and Management, 140(7), 04014020.

Devellis, R.F. (1991). Scale Development. Sage Publications. Pp. 24-33.

Doloi, H., Sawhney, A., Iyer, K. C., and Rentala, S. (2012). "Analysing factors affecting delays in Indian construction projects." International Journal of Project Management, 30(4), 479-489.

Faridi, A. S., and El-Sayegh, S. M. (2006). "Significant factors causing delay in the UAE construction industry." Construction Management and Economics, 24(11), 1167-1176.

Flyvbjerg, B., Skamris Holm, M. K., \& Buhl, S. L. (2004). What causes cost overrun in transport infrastructure projects?. Transport reviews, 24(1), 3-18.

Gold, T., Guthrie, D., \& Wank, D. (2002). Social Connections in China: Institutions. Culture, and the Changing Nature of Guanxi (Structural Analysis in the Social Sciences) New York: Cambridge University Press.

Heldman, K. (2005). Risk Management, Harbor Light Press, London.

Hwang, B. G., \& Leong, L. P. (2013). "Comparison of schedule delay and causal factors between traditional and green construction projects.” Technological and Economic Development of Economy, 19(2), 310-330.

Hwang, B. G., Zhao, X., and Goh, K. J. (2014). "Investigating the client-related rework in building projects: The case of Singapore." International Journal of Project Management, 32(4), 698-708.

Hwang, B. G., Zhao, X., \& Tan, L. L. G. (2015). "Green building projects: schedule performance, influential factors and solutions". Engineering, Construction and Architectural Management, 22(3), 327-346.

Kaliba, C., Muya, M., and Mumba, K. (2009). "Cost escalation and schedule delays in road construction projects in Zambia." International Journal of Project Management, 27(5), 522-531.

Kazaz, A., Ulubeyli, S., and Tuncbilekli, N. A. (2012). "Causes of delays in construction projects in Turkey." Journal of Civil Engineering and Management, 18(3), 426-435.

Kaming, P. F., Olomolaiye, P. O., Holt, G. D., and Harris, F. C. (1997). "Factors influencing construction time and cost overruns on high-rise projects in Indonesia." Construction Management and Economics, 15(1), 83-83.

Khoshgoftar, M., Bakar, A. H. A., \& Osman, O. (2010). "Causes of delays in Iranian construction projects.” International Journal of Construction Management, 10(2), 53-69.

Koushki, P. A., Al-Rashid, K., and Kartam, N. (2005). "Delays and cost increases in the construction of private residential projects in Kuwait." Construction Management and Economics, 23(3), 285-294. 
Leishman, D. M. (1991). "Protecting engineer against construction delay claims. NDC.” Journal of Management in Engineering, 7(3), 314-333.

Lo, T. Y., Fung, I. W. H., and Tung, K. C. F. (2006). “Construction delays in Hong Kong civil engineering projects.” Journal of Construction Engineering and Management, 132(6), 636-649.

Loosemore, M., Raftery, J., Reilly, C., and Higgon, D. (2006). Risk Management in Projects, 2 ed., Spon Press.

Lu, W., Shen, L., and Yam, M. C. H. (2008). "Critical success factors for competitiveness of contractors: China study." Journal of Construction Engineering and Management, 134(12), 972-982.

Lu, W., Zhang, L. and Pan. J. (2015). "Identification and analyses of hidden transaction costs in project dispute resolutions." International Journal of Project Management, 33(3), 711-718.

Luo, J., and Gale, A. (2000). "The evolution of the Chinese construction industry." Building Research \& Information, 28(1), 51-58.

Mahamid, I., Bruland, A., and Dmaidi, N. (2012). "Causes of Delay in Road Construction Projects." Journal of Management in Engineering, 28(3), 300-310.

Majid, M. Z. A., and McCaffer, R. (1998). "Factors of non-excusable delays that influence contractors' performance." Journal of Management in Engineering, 14(3), 42-49.

Ministry of Housing and Urban-Rural Development, China (2017). National Construction Industry's Public Monitoring and Service Platform (全国建筑市场监管公共服务平台). Retrieved from http://jzsc.mohurd.gov.cn/asite/jsbpp/index.

Mpofu, B., Mpofu, B., Ochieng, E. G., Ochieng, E. G., Moobela, C., Moobela, C., \& Pretorius, A. (2017). "Profiling causative factors leading to construction project delays in the United Arab Emirates." Engineering, Construction and Architectural Management, 24(2), 346-376.

Nunnally, J., and Bernstein, I. (1994). Psychometric Theory 3 ed., McGraw-Hill Humanities.

Ogunlana, S. O., Promkuntong, K., and Jearkjirm, V. (1996). "Construction delays in a fast-growing economy: comparing Thailand with other economies." International Journal of Project Management, 14(1), 37-45.

Parchamijalal, M., \& Shoar, S. (2017). A hybrid SD-DEMATEL approach to develop a delay model for construction projects. Engineering, Construction and Architectural Management, 24 (4), 629-651.

Pickavance, K. (2010). Delay and Disruption in Construction Contracts, 4 ed., Sweet \& Maxwell.

Ramanathan, C., Narayanan, S. P., \& Idrus, A. B. (2012). Construction delays causing risks on time and cost-a critical review. Construction Economics and Building, 12(1), 37-57.

Santoso, D. S., \& Soeng, S. (2016). "Analyzing Delays of Road Construction Projects in Cambodia: Causes and Effects.” Journal of Management in Engineering, 32(6), 05016020.

Sinesilassie, E. G., Tabish, S. Z. S., \& Jha, K. N. (2017). Critical factors affecting cost performance: a case of Ethiopian public construction projects. International Journal of Construction Management, 1-12.

Sweis, G., Sweis, R., Abu Hammad, A., and Shboul, A. (2008). "Delays in construction projects: The case of Jordan." International Journal of Project Management, 26(6), 665-674.

Toor, S.-U.-R., and Ogunlana, S. (2008). "Problems causing delays in major construction projects in Thailand." Construction Management and Economics, 26(4), 395-408.

Tran, D. Q, Nguyen, L. D. \& Faught A. (2017). Examination of communication processes in design-build project delivery in building construction", Engineering, Construction and Architectural Management, 24(6), 1319-1336.

Yang, J. B., \& Wei, P. R. (2010). “Causes of delay in the planning and design phases for construction projects.” Journal of Architectural Engineering, 16(2), 80-83.

Zavadskas, E. K., Vilutienė, T., Turskis, Z., \& Šaparauskas, J. (2014). Multi-criteria analysis of Projects' performance in construction. Archives of Civil and Mechanical Engineering, 14(1), 114-121

Zhi, H. (1995). "Risk management for overseas construction projects.” International Journal of Project Management, 13(4), $231-231$.

Zou, P. X., Zhang, G., \& Wang, J. (2007). Understanding the key risks in construction projects in China. International Journal of Project Management, 25(6), 601-614. 